\title{
Analisis Etika Kerja Islam dan Etika Penggunaan Komputer terhadap Ketidaketisan Penggunaan Komputer oleh Pengguna Teknologi Informasi di UMKM Kabupaten Bantul
}

\author{
Nila Hidayah \\ Universitas Alma Ata, Jl. Brawijaya No.99, Kasihan, Tamantirto, Bantul, Yogyakarta \\ Email: nila_hidayah8@yahoo.co.id
}

\begin{abstract}
In forensic accounting science information systems become an inseparable part, especially about the ethics in the use of information technology, especially computers as a medium of learning and media work. In every line need to make the right decision is by doing technology investment in organization. One of the implementation of computer technology that can bring big changes (changes that occur in the way of human thinking, both in business problem solving, planning, and decision making) in all aspects of life that will affect the implementation and human perspective on ethics and norms in his life. The purpose of this study was to determine the extent to which unethical computer use by information technology users. The results showed that the work ethic of Islam has no effect on the ethics of computer usage. The ethics of computer usage has a positive effect on the inability of computer usage. While the gender as a factor of moderation does not affect the inability of computer use. Similarly, work experience as a moderating factor does not affect the inappropriateness of computer use.
\end{abstract}

Keywords: Islamic work ethic, computer usage ethics, computer usage, gender, and work experience.

\begin{abstract}
Abstrak
Dalam ilmu akuntansi forensik sistem informasi menjadi bagian yang tidak dapat dipisahkan, terutama mengenai etika dalam penggunaan teknologi informasi khususnya komputer sebagai media pembelajaran dan media bekerja. Pada setiap lini perlu melakukan pengambilan keputusan secara tepat yaitu dengan melakukan investasi teknologi di dalam organisasi. Salah satunya implementasi terhadap teknologi komputer yang dapat membawa perubahan besar (perubahan yang terjadi pada cara berpikir manusia, baik dalam usaha pemecahan masalah, perencanaan, maupun pengambilan keputusan) disegala sisi kehidupan yang sedikit banyak akan berpengaruh terhadap pelaksanaan dan cara pandang manusia terhadap etika dan norma-norma dalam kehidupannya. Tujuan dari penelitian ini adalah untuk menentukan sejauh mana penggunaan komputer yang tidak etis oleh pengguna teknologi informasi. Hasil penelitian menunjukkan bahwa etika kerja (Islam) tidak berpengaruh terhadap etika penggunaan komputer. Etika penggunaan komputer berpengaruh positif terhadap ketidaketisan penggunaan komputer. Sedangkan jenis kelamin sebagai faktor moderasi tidak berpengaruh terhadap ketidaketisan penggunaan komputer. Demikian pula, pengalaman kerja sebagai faktor moderasi tidak mempengaruhi ketidaketisan penggunaan komputer.
\end{abstract}

Kata kunci: etika kerja Islam, etika penggunaan komputer, ketidaketisan penggunaan komputer, jenis kelamin, dan pengalaman kerja.

\section{PENDAHULUAN}

Dalam berbagai lini kehidupan, sistem informasi sangat diperlukan sebagai penunjang dan pendukung aktivitas, baik pada ilmu kesehatan, hukum, sosial, budaya, ekonomi, salah satunya akuntansi, sistem informasi sangat melekat dan berjalan secara berdampingan.
Banyak masalah yang terjadi pada berbagai kasus bisnis yang ada saat ini melibatkan profesi akuntan. Sorotan yang diberikan kepada profesi ini disebabkan oleh berbagai faktor diantaranya praktik-praktik profesi yang mengabaikan standar akuntansi bahkan etika. Perilaku tidak etis merupakan isu yang relevan 
bagi profesi akuntan saat ini. Di Indonesia, isu mengenai etika akuntan berkembang seiring dengan terjadinya beberapa pelanggaran etika, baik yang dilakukan oleh akuntan publik, akuntan intern, maupun akuntan pemerintah (Ludigdo,1999). Pengembangan dan kesadaran etik atau moral memainkan peran kunci dalam semua area profesi akuntansi (Louwers et al. dalam Muawanah dan Indriantoro, 2001). Profesi akuntan tidak terlepas dari etika bisnis yang mana aktivitasnya melibatkan aktivitas bisnis yang perlu pemahaman dan penerapan etika profesi seorang akuntan serta etika bisnis (Ludigdo dan Machfoedz, 1999).

Berbicara mengenai akuntansi dan sistem informasi, pada ilmu akuntansi forensik, sistem informasi juga menjadi bagian yang tidak dapat dipisahkan, terutama mengenai etika dalam penggunaan teknologi informasi khususnya komputer sebagai media pembelajaran dan media bekerja. Maka di setiap lini perlu melakukan pengambilan keputusan secara tepat, salah satunya dengan melakukan investasi teknologi di dalam organisasi. Tetapi perlu diingat bahwa sistem informasi ada di dalam organisasi jauh sebelum kedatangan teknologi informasi. Bahkan, saat ini masih banyak sistem informasi yang ada di dalam organisasi berjalan tanpa menggunakan teknologi didalamnya (Urumsah, 2014).

Bermacam insiden penyalahgunaan komputer dapat kita temui dalam berbagai bentuk aktivitas termasuk salah satunya mengakses Internet untuk tujuan di luar pekerjaan, terkait dan terlibat dalam berbagai kegiatan menyimpang seperti penipuan, plagiarisme, dan pemalsuan (Karim et. al., 2009). Di ranah komunikasi, teknologi Internet telah menggeser paradigma linear (satu arah) dalam bermedia. Internet telah membuat batasan antara sender dan receiver menjadi kabur. Internet mendapat julukan sebagai media baru (new media) melengkapi tiga media tradisional atau media konvensional lainnya (radio, televisi, dan media cetak). Sebagai media baru, Internet lebih interaktif dan memberikan otonomi kepada user untuk menjadi peserta aktif, bahkan pada kondisi tertentu, dapat sejajar dengan jurnalis (Denis McQuail, 2000 dalam Wijayana, 2009). Internet memungkinkan siapa saja bisa mempublikasikan informasi dengan cepat dan instan dengan biaya kecil (zero cost). Implementasi terhadap teknologi komputer bagi masyarakat dapat membawa perubahan besar disegala sisi kehidupan. Perubahan tersebut meliputi perubahan yang terjadi pada cara berpikir manusia, baik dalam usaha pemecahan masalah, perencanaan, maupun pengambilan keputusan yang sedikit banyak akan berpengaruh terhadap pelaksanaan dan cara pandang manusia terhadap etika dan norma-norma dalam kehidupannya.

Teknologi komputer yang handal menyediakan berbagai kemampuan yang pada gilirannya memberi banyak pilihan baru untuk tindakan yang dapat dilakukan oleh pemakainya. Pilihan yang dimaksud bisa saja pilihan untuk tindakan yang baik dan menguntungkan, tetapi bisa juga untuk tindakan yang buruk dan merugikan pengguna lainnya. Hal di atas berkaitan dengan penelitian terdahulu yaitu etika kerja Islam yang secara signifikan berhubungan dengan etika penggunaan komputer (Mohamed, Karim, dan Hussein, 2012). Kemudian penelitian sebelumnya yang berhubungan dengan ketidaketisan penggunaan komputer disajikan melalui pengembangan UECUBS (Unethical Computer Using Behavior Scale), karena faktorfaktor tertentu yang dapat diidentifikasi mampu menjelaskan etika komputer (Namlu dan Odabasi, 2007). Banerjee (1996) menjabarkan bahwa jenis kelamin berhubungan secara signifikan dengan perilaku etis dari pengguna sistem informasi. Kemudian penelitian terdahulu yang dilakukan oleh Usman (2011) menyatakan bahwa semakin tinggi tingkat pendidikan dan pengalaman kerja karyawan maka akan semakin tinggi kinerja yang ditampilkan. Dalam hal ini kinerja karyawan berupaya untuk dihubungkan dengan perilaku etis. Tetapi dalam penelitiannya, Banerjee (1996) menyatakan bahwa lamanya pengalaman dalam bekerja dan posisi pekerjaan tidak berhubungan dengan perilaku etis di organisasi. Sedangkan Dawson (1997) menemukan cukup bukti bahwa standar etis menjadi lebih tinggi sejalan dengan lamanya pengalaman dalam bekerja.

Beberapa penelitian terdahulu yang telah diuraikan di atas menjadi sebuah penjelas bahwa terus berkembang dan meluasnya 
penyalahgunaan komputer pada organisasi dan oleh karenanya hal ini tidak dapat terelakkan bagi pengguna dalam masyarakat berbasis pengetahuan (Peterson, 2002; Loch dan Conger, 1996). Oleh sebab itu, dalam berbagai organisasi, kebijakan dan pelatihan sumberdaya manusia dikembangkan demi terciptanya kesadaran akan etika dan penggunaan komputer sebagaimana mestinya (Karim et. al., 2009).

Penelitian-penelitian terdahulu telah dilakukan untuk mengetahui etika penggunaan komputer. Salah satunya Mohamed, Karim, dan Hussein (2012) telah melakukan penelitian dengan sampel mahasiswa dan staf akademik dalam lembaga pendidikan tinggi di Malaysia. Dalam penelitian ini, peneliti berupaya untuk melakukan eksplorasi lebih dalam dan variasi lebih beragam dari penelitian sebelumnya. Sebatas pengetahuan penulis, penelitian ini masih jarang dilakukan. Pada era seperti saat ini yang rentan terhadap penyalahgunaan penggunaan komputer, sesuatu yang penting untuk diketahui oleh masyarakat bahwa etika komputer merupakan salah satu dari sekian banyak hal yang perlu diterapkan dalam penggunaan komputer. Hal tersebut sejalan dengan pendapat yang dikemukakan oleh Jananto (2003) bahwa sebagai implikasi dari perkembangan teknologi yang cukup pesat dan kebiasaan atau budaya baru dalam masyarakat, maka dewasa ini ada perhatian yang sangat besar terhadap permasalahan etika dalam penggunaan komputer dan diperkuat dengan tiga alasan utama diperlukannya etika menurut Moor (1985), yakni kelenturan logika (logical malleability), faktor transformasi (transformation factor), dan faktor tidak kasat mata (invisibility factor) di mana ketiganya merupakan cerminan individu dalam menerapkan etika penggunaan komputer guna meminimalisir ketidaketisan penggunaan komputer.

\section{KAJIAN LITERATUR DAN PENGEMBANGAN HIPOTESIS}

\section{Sistem Informasi}

Sistem informasi adalah sebuah rangkaian prosedur formal di mana data dikelompokkan, diproses menjadi informasi, dan didistribusikan kepada pemakai (Kadir, 2014). Sedangkan menurut Krismiaji (2015) sistem informasi adalah cara-cara yang diorganisasi untuk mengumpulkan, memasukkan, dan mengolah serta menyimpan data, dan cara-cara yang diorganisasi untuk menyimpan, mengelola, mengendalikan, dan melaporkan informasi sedemikian rupa sehingga sebuah organisasi dapat mencapai tujuan yang telah ditetapkan.

\section{Teknologi Informasi}

Teknologi informasi merupakan sarana untuk memfasilitasi, mengakuisisi, memproses, menyimpan, menyampaikan, dan membagi informasi (Urumsah, 2014). Selanjutnya teknologi informasi menurut Mulyadi (2014) mencakup komputer (baik perangkat keras dan perangkat lunak), berbagai peralatan kantor elektronik, perlengkapan pabrik dan telekomunikasi.

\section{Etika}

Secara etimologis etika dan moral berarti sama yaitu adat kebiasaan. Etika berasal dari bahasa Yunani kuno 'ethos' dan jamaknya 'taetha', dan moral berasal dari bahasa Latin 'mos' dan jamaknya 'mores' (Bertens, 2007). Etika berkaitan dengan pertanyaan tentang bagaimana orang akan berperilaku terhadap sesamanya (Kell et. al., 2002). Maryani dan Ludigdo (2001) mendefinisikan etika sebagai seperangkat aturan atau norma atau pedoman yang mengatur perilaku manusia, baik yang harus dilakukan maupun yang harus ditinggalkan yang dianut oleh sekelompok atau segolongan manusia atau masyarakat atau profesi.

\section{Etika Komputer}

Etika komputer dapat didefinisikan sebagai kategori etika profesional yang hampir sama dengan medis, hukum, mengajar, dan akuntansi (Baaese, 2003). Sedangkan Moor (1985) mendefinisikan etika komputer sebagai analisis sifat dan dampak sosial teknologi komputer serta perumusan dan justifikasi dari kebijakan-kebijakan yang terkait untuk penggunaan teknologi tersebut secara etis.

\section{Ketidaketisan Penggunaan Komputer}

Ketidaketisan penggunaan komputer adalah suatu kondisi dalam penggunaan 
komputer saat terjadi penyimpangan dan mengarah pada suatu hal yang tidak etis. Dalam penelitian ini etika penggunaan komputer dihubungkan dengan ketidaketisan penggunaan komputer. Namlu dan Odabasi (2007) menyatakan bahwa pengembangan Unethical Computer Using Behavior Scale (dalam hal ini ketidaketisan penggunaan komputer) karena faktor-faktor tertentu yang dapat diidentifikasi mampu menjelaskan etika komputer.

\section{Faktor-faktor Ketidaketisan Penggunaan Komputer}

Penelitian ini membahas tentang ketidaketisan penggunaan komputer yang dipengaruhi oleh variabel etika kerja Islam, etika penggunaan komputer serta jenis kelamin dan pengalaman kerja.

\section{Etika Kerja Islam}

Etika kerja Islami (Islamic work ethic) merupakan orientasi yang membentuk dan mempengaruhi keterlibatan dan partisipasi muslim di tempat kerja (Ali dan Owaihan, 2008). Sedangkan menurut Asifudin (2004), etos kerja dalam perspektif Islam diartikan sebagai pancaran dari aqidah yang bersumber dari pada sistem keimanan Islam, yakni sebagai sikap hidup yang mendasar berkenaan dengan kerja, sehingga dapat dibangun paradigma etos kerja yang Islami. Karakteristik-karakteristik etos kerja Islami digali dan dirumuskan berdasarkan konsep (1) kerja merupakan penjabaran aqidah (2) kerja dilandasi ilmu (3) kerja dengan meneladani sifat-sifat Ilahi serta mengikuti petunjuk-petunjukNya.

\section{Etika Penggunaan Komputer}

Etika dalam penggunaan komputer merupakan hal yang penting untuk membatasi adanya penyalahgunaan teknologi atau komputer yang dapat merugikan orang lain. Dengan adanya etika dalam penggunaan komputer segala kegiatan yang dilakukan dalam dunia komputer memiliki aturan-aturan atau nilai yang mempunyai dasar ilmu yang jelas dan dapat dipertanggungjawabkan. Sehingga etika dalam penggunaan komputer dapat membatasi hal-hal yang dilarang untuk dilakukan bahkan membatasi kegiatan yang dapat menimbulkan pelanggaran dalam penggunaan komputer (Kadafi, 2012).

\section{Pengaruh Moderasi sebagai Faktor Demografis}

Dalam penelitian ini terdapat faktor demografis yaitu jenis kelamin dan pengalaman kerja sebagai faktor moderasi. Dua faktor demografis tersebut akan diuji sebagai faktor moderasi dalam penelitian ini.

\section{Jenis Kelamin}

Jenis kelamin adalah suatu konsep analisis yang digunakan untuk mengidentifikasi perbedaan laki-laki dan perempuan dilihat dari sudut non-biologis, yaitu dari aspek sosial, budaya, maupun psikologis (Mutmainah, 2006).

\section{Pengalaman Kerja}

Pengalaman kerja adalah ukuran tentang lama waktu atau masa kerja yang telah ditempuh seseorang dapat memahami tugastugas suatu pekerjaan dan telah melaksanakan dengan baik (Ranupandojo, 1984).

\section{Kerangka Pengembangan Hipotesis}

\section{Etika Kerja Islam dan Etika Penggunaan Komputer}

Etika kerja Islam telah menarik perhatian para peneliti, di mana nilai perorangan untuk etika kerja dapat dipandang dari perspektif pekerjaan serta perspektif religius dan moral. Pada penelitian terdahulu yang dilakukan oleh Mohamed, Karim, dan Hussein (2012) etika kerja Islam yang secara signifikan berhubungan dengan etika penggunaan komputer. Dari uraian di atas maka diajukan hipotesis sebagai berikut:

\section{H1 : Etika Kerja Islam Berpengaruh Positif terhadap Etika Penggunaan Komputer.}

\section{Etika Penggunaan Komputer dan \\ Ketidaketisan Penggunaan Komputer}

Sebuah penelitian yang bertujuan untuk mengembangkan UECUBS (dalam hal ini ketidaketisan penggunaan komputer) menunjukkan bahwa faktor-faktor tertentu 
yang dapat diidentifikasi mampu menjelaskan etika komputer dikemukakan oleh Namlu dan Odabasi (2007). Kuo dan Hsu (2001) menyatakan bahwa tindakan tidak etis dalam penggunaan komputer juga berupa pemfitnahan tanpa nama (anonymous defamation), penyebaran virus komputer, pembajakan software, dan invasi hackers pada situs jaringan. Dari uraian tersebut diajukan hipotesis sebagai berikut:

\section{H2 : Etika Penggunaan Komputer Berpengaruh Positif terhadap Ketidaketisan Penggunaan Komputer.}

\section{Hipotesis yang Berhubungan dengan Jenis Kelamin}

Kajian mengenai jenis kelamin dan etika semakin berkembang dan mendapatkan perhatian yang besar. Dapat diprediksi bahwa jenis kelamin berhubungan dengan ketidaketisan penggunaan komputer. Kreie dan Cronan (1998) memberi kesimpulan bahwa pria dan wanita memiliki perbedaan mencolok dalam penaksiran mereka terkait dengan perilaku etis dan tidak etis. Namun pada penelitian yang dilakukan Mohamed, Karim, dan Hussein (2012) menyatakan bahwa jenis kelamin tidak berhubungan secara signifikan terhadap etika penggunaan komputer. Dengan adanya ketidaksesuaian dari hasil penelitian sebelumnya, maka perlu justifikasi untuk diteliti lebih lanjut dan diajukan hipotesis sebagai berikut:
H3 : Jenis Kelamin sebagai Faktor Moderasi Berpengaruh Positif terhadap Ketidaketisan Penggunaan Komputer.

\section{Hipotesis yang Berhubungan dengan Pengalaman Kerja}

Pada peneliti sebelumnya berupaya untuk menghubungkan pengalaman kerja dengan etika. Adapun prediksi bahwa pengalaman kerja berhubungan dengan ketidaketisan penggunaan komputer. Dalam penelitian terdahulu yang dilakukan oleh Dawson (1997) menemukan cukup bukti bahwa standar etis menjadi lebih tinggi sejalan dengan lamanya pengalaman dalam bekerja. Sedangkan menurut Banerjee (1996) bahwa lamanya pengalaman dalam bekerja seseorang dan posisi pekerjaan tidak berhubungan dengan perilaku etis di organisasi. Maka, dengan munculnya ketidaksesuaian dari hasil penelitian sebelumnya perlu adanya justifikasi untuk diteliti lebih mendalam dan diajukan hipotesis sebagai berikut:

\section{H4 : Pengalaman Kerja sebagai Faktor Moderasi Berpengaruh Positif terhadap Ketidaketisan Penggunaan Komputer.}

\section{Kerangka Pemikiran}

Kerangka pemikiran merupakan model konseptual tentang bagaimana teori berhubungan dengan berbagai faktor yang

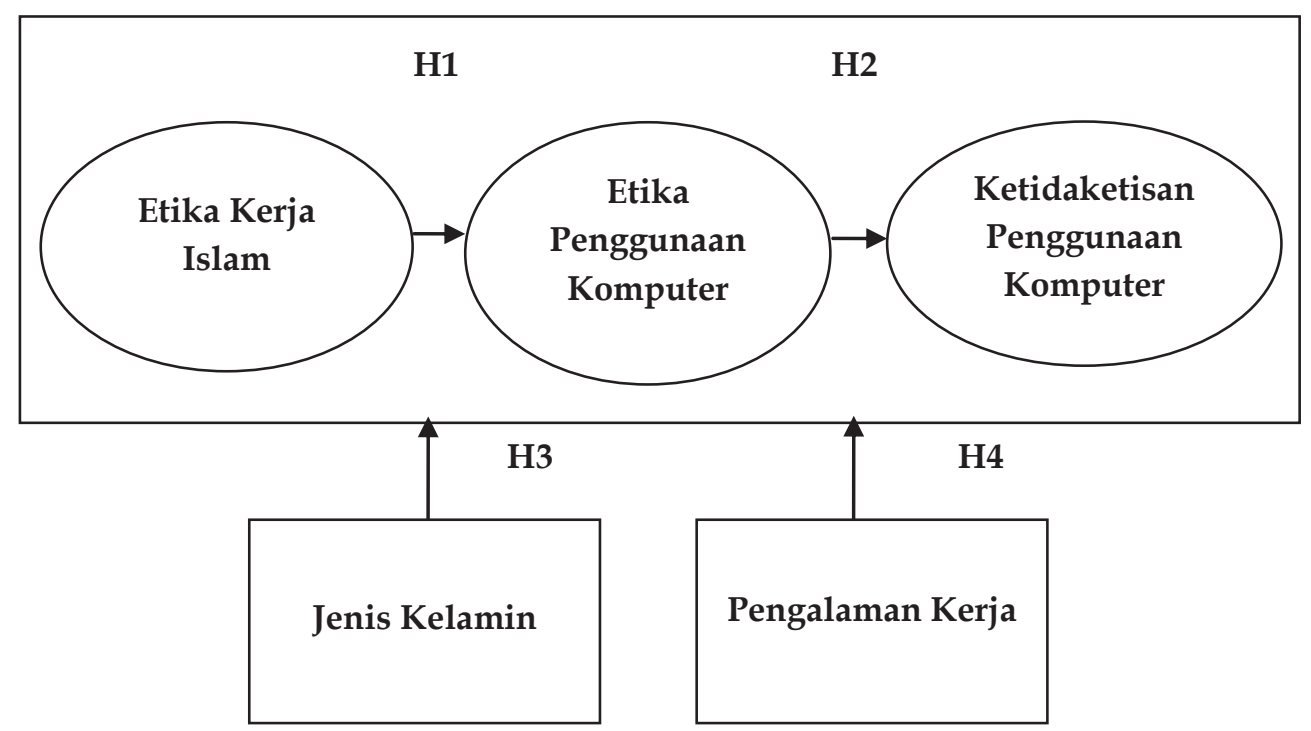

Gambar 1. Kerangka Pemikiran 
telah diidentifikasi sebagai masalah yang penting. Kerangka pemikiran yang baik akan menjelaskan secara teoritis pertautan antara faktor yang diteliti. Pada penelitian kali ini kerangka pemikiran terdiri dari faktor independen, faktor intervening, faktor dependen, dan faktor moderasi. Kerangka teoritis dalam penelitian ini memadukan faktor Etika Kerja Islam yang berpengaruh terhadap Etika Penggunaan Komputer, faktor Etika Penggunaan Komputer yang berpengaruh terhadap Ketidaketisan Penggunaan Komputer, serta faktor Jenis Kelamin dan Pengalaman Kerja sebagai faktor moderasi yang berpengaruh terhadap Ketidaketisan Penggunaan Komputer. Oleh karena itu, kerangka konseptual yang dikembangkan dalam model ini adalah sebagai berikut :

\section{METODE PENELITIAN}

\section{Desain Penelitian}

Penelitian ini menggunakan metode survei yang merupakan cara untuk mengumpulkan informasi secara luas dari sekumpulan subjek yang berkepentingan. Faktor yang akan diteliti pada penelitian ini meliputi faktor independen yaitu etika kerja Islam, faktor intervening yaitu etika penggunaan komputer, faktor dependen yaitu ketidaketisan penggunaan komputer, serta faktor moderasi yaitu jenis kelamin dan pengalaman kerja.

\section{Populasi dan Sampel}

Populasi dan sampel merupakan dua hal yang saling berkaitan dan bermanfaat dalam proses pengumpulan data dalam melakukan sebuah penelitian.

\section{Populasi}

Populasi pada penelitian ini adalah karyawan kelompok UMKM (Usaha Mikro Kecil Menengah).

\section{Sampel}

Dalam penelitian ini yang menjadi sampel adalah karyawan admin pengguna teknologi informasi pada UMKM (Usaha Mikro Kecil Menengah) di Kabupaten Bantul.

\section{Teknik Pengambilan Sampel}

Teknik pengambilan sampel yang digunakan dalam penelitian ini adalah non probability sampling. Menurut Sugiyono (2012) non probability sampling adalah teknik yang tidak memberi peluang atau kesempatan yang sama bagi setiap unsur atau anggota populasi untuk dipilih menjadi sampel. Sedangkan pemilihan responden berdasarkan convenience sampling yaitu informasi diambil dari anggota populasi yang bersedia mengisi kuesioner (Sekaran, 2003). Dalam proses pengisian kuesioner, para responden tidak perlu memberikan identitas guna menjamin kerahasiaan responden.

\section{Teknik Pengumpulan Data}

Dalam penelitian ini, teknik pengumpulan data yang digunakan adalah dengan teknik survei. Survei adalah teknik pengumpulan dengan memberikan pertanyaan-pertanyaan kepada responden individu (Hartono, 2007). Peneliti secara langsung menyebarkan kuesioner penelitian kepada responden dengan meminta izin dan waktu para responden, menjelaskan penelitian secara ringkas dan tata cara pengisian kuesioner sebelum responden mengisi kuesioner tersebut.

\section{Definisi Operasional dan Pengukuran Faktor}

Penelitian ini menggunakan skala likert sebagai skala pengukuran. Skala likert menurut Sugiyono (2014) digunakan untuk mengukur sikap, pendapat, dan persepsi seseorang atau kelompok orang tentang fenomena sosial. Skala likert berhubungan dengan pernyataan tentang sikap seseorang terhadap sesuatu, misalnya setuju-tidak setuju, senang-tidak senang, dan baik-tidak baik (Kinnear (1988) dalam Umar 2011). Dalam penelitian ini indikator diukur dengan skala likert 1 sampai 6, dari Sangat Tidak Setuju sampai Sangat Setuju. Selanjutnya atribut-atribut tersebut beserta indikatornya disusun menjadi sebuah kuesioner dengan memberikan skor terhadap setiap item dari setiap pernyataan yang diajukan.

Sedangkan indikator dari jenis kelamin dan pengalaman kerja berupa pertanyaan dalam profil responden mengenai karakteristik individu dan setiap responden dapat 
mengisikan pada kolom pria atau wanita untuk jenis kelamin dan kolom $<2$ tahun atau $\geq 2$ tahun untuk pengalaman kerja.

\section{Teknik Analisis Data}

Pada penelitian ini digunakan 2 (dua) pengolahan data untuk melakukan analisis yang bersifat deskriptif dan analisis yang bersifat analitik. Analisis yang berkaitan dengan penjelasan berbagai perilaku variabel dilakukan dengan analisis deskriptif berdasarkan pada berbagai teori dan pendekatan yang relevan. Analisis yang memiliki keterkaitan antara berbagai variabel dilakukan dengan pendekatan uji statistik berupa analisis persamaan simultan Simultaneous Equation Model (SEM) yang dibantu dengan program aplikasi smartPLS versi 2.0. Uji validitas dilakukan dengan membandingkan akar kuadrat dari Average Variance Extracted (AVE) setiap konstruk dengan korelasi antara konstruk dengan konstruk lainnya dalam model. Jika nilai akar kuadrat AVE setiap konstruk lebih besar daripada nilai korelasi antara konstruk dengan konstruk lainnya dalam model, maka dikatakan memiliki nilai discriminant validity yang baik (Fornell dan Larcker, 1981). Untuk uji realibilitas konstruk diukur dengan menggunakan model composite realibility. Suatu konstruk dikatakan reliabel jika nilai composite realibility di atas 0,70 (Ghozali, 2006).

\section{Teknik Analisis Deskriptif}

Teknik analisis deskriptif adalah data yang berbentuk kata, kalimat, skema, dan gambar. Data kualitatif dicatat bukan dengan angka tetapi dengan menggunakan klasifikasiklasifikasi (Sugiyono, 2003). Analisis kualitatif yang digunakan dalam penelitian ini adalah analisis statistik deskriptif. Analisis statistik deskriptif adalah yang berbentuk uraian dari hasil penelitian yang didukung oleh teori dan data yang telah ditabulasi kemudian diikhtisarkan. Analisis ini digunakan untuk memperkuat analisis kuantitatif dengan menginterpretasikan hasil-hasil yang diperoleh dari analisis kuantitatif.

\section{Teknik Analisis Kuantitatif}

Teknik analisis kuantitatif adalah datadata yang berbentuk angka atau kuantitatif yang diangkakan (Sugiyono, 2003). Data kuantitatif yang diangkakan (scoring) misalnya terdapat dalam skala pengukuran. Data kuantitatif yang berwujud angka-angka sebenarnya merupakan bahan dasar dari setiap penyelidikan yang bersifat statistik. Analisa kuantitatif untuk data primer yaitu dengan memberikan skor terhadap setiap item dari setiap pernyataan yang diajukan dengan menggunakan skala likert.

\section{Pengujian Kualitas Data}

Pengujian dengan menggunakan PLS pada dasarnya terdiri atas dua macam pengujian, yaitu model pengukuran (outer model) dan struktural model (inner model) (Ghozali, 2006).

\section{Model Pengukuran (Outer Model)}

\section{Uji Validitas}

Menurut Cooper dan Schindler (2006) uji validitas dilakukan untuk mengetahui kemampuan instrumen penelitian mengukur apa yang seharusnya diukur. Validitas variabel menunjukkan seberapa baik hasil yang diperoleh dari penggunaan suatu pengukuran sesuai teoriteori yang digunakan untuk mendefinisikan suatu variabel. Sebuah instrumen dikatakan valid atau sahih apabila dapat mengungkap data variabel yang diteliti secara tepat (Arikunto, 2006). Uji validitas dilakukan terhadap seluruh pernyataan yang ada dalam setiap variabel, yaitu untuk mengetahui tingkat kevalidan setiap pernyataan terhadap variabel penelitian. Varian yang didasarkan pada pendekatan PLS lebih sering digunakan karena PLS tidak mengharuskan pembebanan sampel dan merupakan distribusi bebas. Selain itu juga dilakukan dengan melihat nilai Average Variance Extracted (AVE). Menurut Fornell dan Larcker (1981) nilai AVE harus lebih besar dari 0,5 .

\section{Uji Reliabilitas}

Reliabilitas menunjukkan akurasi, konsistensi, dan ketepatan suatu alat ukur dalam melakukan pengukuran (Hartono, 2008). Ada 2 (dua) metode yang dapat digunakan untuk menguji reliabilitas dalam PLS, yaitu cronbach's alpha dan composite reliability (Abdillah dan Jogiyanto, 2009). Pengukuran reliabilitas 
konstruk dalam penelitian ini akan diukur dengan menggunakan composite reliability yaitu indeks yang menunjukkan sejauh mana suatu alat ukur dapat dipercaya dan dapat diandalkan. Suatu konstruk dikatakan reliabel jika nilai composite reliability di atas 0,70 (Ghozali, 2006). Kemudian diperkuat pula dengan pendapat Hair et. al., (2006) bahwa nilai composite reliability harus lebih besar dari 0,70 meskipun nilai 0,60 masih dapat diterima.

\section{Model Struktural (Inner Model)}

Menurut Ghozali (2006) pengujian inner model atau model struktural dilakukan untuk melihat hubungan antara konstruk, nilai signifikansi dan $R$-Square dari model penelitian.

\section{Uji R-Square $\left(\mathbf{R}^{2}\right)$}

Pengukuran persentase pengaruh semua variabel independen terhadap nilai variabel dependen ditunjukkan oleh besarnya koefisien determinasi $R$-Square $\left(R^{2}\right)$ antara satu dan nol, di mana nilai $R$-Square $\left(R^{2}\right)$ yang mendekati satu memberikan persentase pengaruh yang besar (Ghozali, 2006).

\section{Uji T-Statistik}

Uji t digunakan untuk menguji signifikansi konstanta dan variabel independen yang terdapat dalam persamaan tersebut secara individu apakah berpengaruh terhadap nilai variabel dependen. Pengujian ini dilakukan dengan melihat output dengan bantuan program aplikasi PLS Graph. Jika nilai t-hitung $>$ t-tabel $(1,64)$ pada taraf signifikansi $5 \%$ maka diterima atau signifikan (Ghozali, 2006).

\section{Path Coefficient}

Path coefficient merupakan suatu model analisis jalur yang secara sistematis untuk membandingkan berbagai jalur yang bisa mempengaruhi secara langsung atau tidak langsung antara variabel bebas terhadap variabel terikat (Ghozali, 2006).

\section{HASIL DAN PEMBAHASAN}

\section{Evaluasi Pengukuran (Outer Model)}

\section{Uji Validitas}

Chin (1998) menjelaskan bahwa convergent validity dari model pengukuran dengan refleksif indikator dinilai berdasarkan korelasi antara item score atau component score dengan construct score yang dihitung dengan PLS. Ukuran refleksif individual dikatakan tinggi jika berkorelasi lebih dari 0,70 dengan konstruk yang ingin diukur. Namun demikian untuk penelitian tahap awal dari pengembangan skala pengukuran nilai loading 0,50 sampai 0,60 dianggap cukup.

Sedangkan Fornell dan Larcker (1981) memaparkan bahwa discriminant validity dari model pengukuran dengan refleksif indikator dinilai berdasarkan cross loading pengukuran dengan konstruk. Metode lain untuk menilai discriminant validity adalah dengan membandingkan nilai square root of average variance extracted (AVE) setiap konstruk dengan korelasi antara konstruk dengan konstruk lainnya dalam model. Jika akar kuadrat AVE setiap konstruk lebih besar daripada nilai korelasi antara konstruk dengan konstruk lainnya dalam model, maka memiliki nilai discriminant validity yang baik.

Tabel 1. Item Loading Akhir dan AVE dalam Model Akhir Etika Komputer

\begin{tabular}{clccc}
\hline Konstruk & \multicolumn{1}{c}{ Variabel } & Items & Loading & AVE \\
\hline \multirow{2}{*}{ Etika Kerja Islam } & Kualitas kerja optimal & EKI3 & 0,8429 \\
& Eksploitasi dalam bekerja & EKI4 & 0,7967 & 0,6281 \\
& Kemampuan diri & EKI6 & 0,7342 & \\
& Akses sistem komputer tidak sah & EPK2 & 0,9155 & 0,7688 \\
Etika Penggunaan & Tidak melakukan log out & EPK3 & 0,7911 & 0 \\
Komputer & Sumber daya kantor untuk keuntungan pribadi & EPK4 & 0,9179 \\
& Mengakses file pribadi orang lain & KPK7 & 0,9501 \\
Ketidaketisan & Mengakses komputer pribadi orang lain & KPK8 & 0,9682 & 0,9093 \\
& Penggunaan Komputer & KPK9 & 0,9423 & \\
& Jaringan tanpa izin & &
\end{tabular}

Sumber: Data Diolah 
Tabel 2. Cross Loading

\begin{tabular}{cccc}
\hline & EKI & EPK & KPK \\
\hline EKI 3 & 0,8429 & $-0,6621$ & $-0,6506$ \\
EKI 4 & 0,7967 & $-0,5987$ & $-0,4489$ \\
EKI 6 & 0,7342 & $-0,3672$ & $-0,1675$ \\
EPK 2 & $-0,7172$ & 0,9155 & 0,6334 \\
EPK 3 & $-0,5546$ & 0,7911 & 0,7713 \\
EPK 4 & $-0,5948$ & 0,9179 & 0,5867 \\
KPK 7 & $-0,5931$ & 0,6907 & 0,9501 \\
KPK 8 & $-0,6014$ & 0,7555 & 0,9682 \\
KPK 9 & $-0,4755$ & 0,7351 & 0,9423 \\
\hline
\end{tabular}

Sumber: Data Diolah

Dalam Tabel 1 memaparkan bahwa AVE pada konstruk Etika Kerja Islam (EKI), Etika Penggunaan Komputer (EPK), dan Ketidaketisan Penggunaan Komputer (KPK) telah menghasilkan AVE dan loading factor lebih dari 0,5 dengan cara mengeluarkan beberapa indikator dalam setiap konstruk yang menghasilkan angka di bawah 0,5. Maka indikator yang dipergunakan dalam penelitian ini adalah valid atau telah memenuhi convergent validity.

Dalam Tabel 2 menunjukkan bahwa tidak terdapat korelasi item pernyataan variabel lain yang nilainya melebihi korelasi item pernyataan antara item pernyataan itu sendiri.

\section{Uji Reliabilitas}

Pada saat akan mengukur reliabilitas dari data konstruk yang ada dapat menggunakan composite reliability. Konstruk dinyatakan reliabel jika nilai composite reliability di atas 0,70. Berikut ini adalah hasil perhitungan konstruk yang dirangkum dalam internal composite reliability dan hubungan antar konstruk yang disajikan dalam Tabel 3.

Tabel 3. Internal Composite Reliability dan Hubungan Antar Konstruk

\begin{tabular}{ccccc}
\hline & ICR & EKI & EPK & KPK \\
\hline EKI & 0,8347 & $\mathbf{0 , 7 9 2 5}$ & & \\
EPK & 0,9085 & $-0,7141$ & $\mathbf{0 , 8 7 6 8}$ & \\
KPK & 0,9678 & $-0,5833$ & 0,7634 & $\mathbf{0 , 9 5 3 6}$ \\
\hline
\end{tabular}

Catatan: unsur-unsur yang dicetak tebal pada diagonal utama merupakan akar pangkat dari AVE.

Tabel 3 menunjukkan bahwa nilai composite reliability untuk semua konstruk adalah di atas
0,70 yang menunjukkan bahwa semua konstruk pada model yang diestimasi memenuhi kriteria discriminant validity. Nilai composite reliability yang terendah adalah sebesar 0,8347 pada konstruk Etika Kerja Islam (EKI).

\section{Menilai Inner Model atau Model Struktural Hasil Penelitian}

Setelah model yang diestimasi memenuhi kriteria outer model, berikutnya dilakukan pengujian model struktural (inner model).

\section{Uji $R$-Square $\left(R^{2}\right)$}

Tabel 4. $R^{2}$ Value untuk Model Etika Komputer

\begin{tabular}{lc}
\hline \multicolumn{1}{c}{ Konstruk } & $\boldsymbol{R}$-Square $\left(\boldsymbol{R}^{2}\right)$ \\
\hline Etika Kerja Islam & - \\
Etika Penggunaan Komputer & 0,5100 \\
Ketidaketisan Penggunaan & \\
Komputer & 0,5828 \\
\hline
\end{tabular}

Sumber: Data Diolah

Tabel 4 memberikan nilai 0,5100 untuk konstruk Etika Penggunaan Komputer (EPK) yang berarti bahwa 0,5100 dipengaruhi oleh Etika Kerja Islam (EKI) dan Ketidaketisan Penggunaan Komputer (KPK) dengan varians EPK sebesar $51 \%$. Oleh karena itu, sebanyak $49 \%$ dipengaruhi variabel lain. Nilai $R$-Square juga terdapat pada Ketidaketisan Penggunaan Komputer (KPK) dengan nilai 0,5828. Hal tersebut menunjukkan bahwa 0,5828 dipengaruhi oleh Etika Penggunaan Komputer (EPK) dengan varians KPK sebesar 58,28\%. Sehingga, kurang lebih $42 \%$ dipengaruhi oleh variabel lain.

\section{Penilaian Model Struktural}

Dalam penelitian ini terdapat klasifikasi responden berdasarkan jenis kelamin yang terdiri dari pria dan wanita serta klasifikasi responden berdasarkan pengalaman kerja yang terdiri dari $<2$ tahun atau $\geq 2$ tahun.

Tabel 5 menunjukkan bahwa semua loading factor berada di atas 0,5 atau telah sesuai dengan nilai yang disarankan.

Tabel 6 menunjukkan bahwa Gambar 3 hingga 6 menghasilkan kesimpulan yang diperoleh dari keseluruhan antara konstruk dalam setiap kelompok. 
Tabel 5. Loading Factor, Composite Reliability (CR) dan AVE pada Setiap Kelompok

\begin{tabular}{ccccccccc}
\hline \multirow{2}{*}{ Items } & \multicolumn{2}{c}{ Pria } & \multicolumn{2}{c}{ Wanita } & \multicolumn{2}{c}{$<$ 2 Tahun } & \multicolumn{2}{c}{$\geq$ 2 Tahun } \\
& Loading & t-Statistic & Loading & $t$-Statistic & Loading & t-Statistic & Loading & $t$-Statistic \\
\hline EKI 3 & $-0,7329$ & 1,1176 & 0,8563 & 13,5047 & 0,8846 & 22,3204 & 0,7786 & 6,9489 \\
EKI 4 & $-0,5579$ & 0,8792 & 0,8329 & 7,6827 & 0,7107 & 6,5232 & 0,8260 & 4,4196 \\
EKI 6 & $-0,6394$ & 0,9665 & 0,7955 & 7,4551 & 0,7777 & 9,3524 & 0,9015 & 5,7684 \\
EPK 2 & 0,9536 & 2,0940 & 0,9771 & 81,2948 & 0,9199 & 32,1356 & 0,9321 & 18,3267 \\
EPK 3 & $-0,7696$ & 1,3971 & 0,9227 & 14,9580 & 0,6954 & 3,8199 & 0,9064 & 13,9562 \\
EPK 4 & 0,6015 & 1,6423 & 0,9275 & 35,0531 & 0,9148 & 37,9573 & 0,9270 & 27,4744 \\
KPK 7 & 0,7314 & 2,0613 & 0,9657 & 23,5574 & 0,9691 & 7,4155 & 0,8448 & 6,7449 \\
KPK 8 & 0,9451 & 2,3511 & 0,9704 & 37,1039 & 0,9626 & 6,9289 & 0,9759 & 42,1942 \\
KPK 9 & 0,7435 & 1,8182 & 0,9768 & 149,8851 & 0,9742 & 7,1389 & 0,8997 & 35,0331 \\
Construct & CR & AVE & CR & AVE & $\mathbf{C R}$ & AVE & CR & AVE \\
EKI & 0,6813 & 0,4190 & 0,8678 & 0,6866 & 0,8356 & 0,6308 & 0,8748 & 0,7004 \\
EPK & 0,3518 & 0,6212 & 0,9599 & 0,8888 & 0,8848 & 0,7222 & 0,9444 & 0,8499 \\
KPK & 0,8518 & 0,6603 & 0,9802 & 0,9428 & 0,9785 & 0,9382 & 0,9338 & 0,8251 \\
\hline
\end{tabular}

Sumber: Data Diolah

Tabel 6. Hasil Keseluruhan antara Konstruk dalam Setiap Kelompok

\begin{tabular}{ccc}
\hline & EKI-EPK & EPK-KPK \\
\hline Pria & ts & ts \\
Wanita & ts & $\mathrm{s}$ \\
$<2$ Tahun & ts & $\mathrm{s}$ \\
$\geq 2$ Tahun & ts & $\mathrm{s}$ \\
\hline
\end{tabular}

\begin{tabular}{ll}
\hline EKI & : Etika Kerja Islam \\
EPK & : Etika Penggunaan Komputer \\
KPK & : Ketidaketisan Penggunaan Komputer \\
$\mathrm{S}$ & : signifikan \\
ts & : tidak signifikan
\end{tabular}

\section{Keterkaitan Subgrup Path}

Ketika sampel tidak berdistribusi normal dan varian dari kelompok yang berbeda, maka untuk memeriksa efek pengaruh jenis kelamin dan pengalaman kerja digunakan Smith-Satterwait untuk menghitung t-test dengan kesalahan yang terkumpul (Moores dan Chang, 2006).

Tabel 7a dan $7 \mathrm{~b}$ pada $\mathrm{H} 3$ menunjukkan bahwa jenis kelamin telah terbukti sebagai variabel moderasi untuk hubungan antara etika kerja Islam dan etika penggunaan komputer dengan nilai t-statistik sebesar 2,2304 yang lebih besar dari nilai t-value 1,64 (alpha 5\%). Sama halnya bahwa jenis kelamin juga telah terbukti sebagai variabel moderasi untuk hubungan antara etika penggunaan komputer dan ketidaketisan penggunaan komputer dengan nilai t-statistik sebesar $-4,8163$ yang lebih besar dari nilai t-value 1,64 (alpha 5\%). Maka dapat disimpulkan bahwa variabel jenis kelamin terbukti sebagai variabel moderator sebab dari 2 hubungan yang dibangun seluruhnya telah menunjukkan bahwa jenis kelamin terbukti sebagai variabel moderasi.

Sedangkan pada $\mathrm{H} 4$ tidak menunjukkan bahwa pengalaman kerja terbukti sebagai variabel moderasi untuk hubungan antara etika kerja Islam dan etika penggunaan komputer sebab nilai t-statistik -1,4555 lebih kecil dari nilai t-value 1,64 (alpha 5\%). Sama halnya bahwa pengalaman kerja juga tidak terbukti sebagai variabel moderasi untuk hubungan antara etika penggunaan komputer dan ketidaketisan penggunaan komputer dengan nilai t-statistik 1,4511 yang lebih kecil dari nilai t-value 1,64 (alpha 5\%). Maka dapat disimpulkan bahwa variabel pengalaman kerja tidak terbukti sebagai variabel moderator sebab dari 2 hubungan yang dibangun seluruhnya tidak menunjukkan bahwa pengalaman kerja terbukti sebagai variabel moderasi.

\section{Pengujian Hipotesis}

Berikut ini adalah hasil pengujian hipotesis yang disajikan, baik untuk kelompok keseluruhan, maupun kelompok jenis kelamin dan pengalaman kerja.

\section{Hasil Penelitian}

Hasil analisis pada bagian ini diinterpretasikan dan didiskusikan dengan memberikan beberapa penjelasan. Bagian 
Tabel 7a dan 7b. Hasil Hubungan antara t-test dengan Kesalahan Terkumpul oleh Subgrup

\begin{tabular}{|c|c|c|c|c|c|c|}
\hline \multirow{2}{*}{ Hipotesis } & \multicolumn{3}{|c|}{ Pria } & \multicolumn{2}{|c|}{ Wanita } & \multirow{2}{*}{ t-Statistic } \\
\hline & Path & Path Coeff. & SE dari Boots & Path Coeff. & SE dari Boots & \\
\hline $\mathrm{H} 3$ & EKI $\rightarrow$ EPK & 0,893 & 0,7547 & $-0,800$ & 0,0813 & 2,2304 \\
\hline $\mathrm{H} 3$ & $\mathrm{EPK} \rightarrow \mathrm{KPK}$ & $-0,493$ & 0,2967 & 0,940 & 0,0222 & $-4,8163$ \\
\hline \multirow{2}{*}{ Hipotesis } & & \multicolumn{2}{|c|}{$<2$ Tahun } & \multicolumn{2}{|c|}{$\geq 2$ Tahun } & t-Statistic \\
\hline & Path & Path Coeff. & SE dari Boots & Path Coeff. & SE dari Boots & t-Statistic \\
\hline $\mathrm{H} 4$ & EKI $\rightarrow$ EPK & $-0,827$ & 0,0647 & $-0,600$ & 0,1419 & $-1,4555$ \\
\hline $\mathrm{H} 4$ & $\mathrm{EPK} \rightarrow \mathrm{KPK}$ & 0,792 & 0,1226 & 0,540 & 0,1230 & 1,4511 \\
\hline
\end{tabular}

Tabel 8. Ringkasan dari Pengujian Hipotesis

\begin{tabular}{llccc}
\hline \multicolumn{1}{c}{ Hipotesis } & $\beta$ & $\boldsymbol{t}$-value & Hasil \\
\hline H1 & $\begin{array}{l}\text { Etika Kerja Islam berpengaruh terhadap Etika } \\
\text { Penggunaan Komputer. }\end{array}$ & $-0,714$ & 9,391 & $\begin{array}{c}\text { Tidak } \\
\text { Didukung }\end{array}$ \\
H2 & $\begin{array}{l}\text { Etika Penggunaan Komputer berpengaruh } \\
\text { terhadap Ketidaketisan Penggunaan Komputer. }\end{array}$ & 0,763 & 8,656 & Didukung \\
H3 & $\begin{array}{l}\text { Jenis Kelamin mempengaruhi } \\
\text { hubungan antar faktor. }\end{array}$ & $-0,893 \&-0,493$ & 2,2304 & Tidak \\
& Pengalaman Kerja mempengaruhi hubungan antar & $-0,827 \& 0,792$ & $-4,8163$ & Didukung \\
H4 & $-0,600 \& 0,540$ & 1,4511 & Tidak \\
& faktor. & & & \\
\hline
\end{tabular}

pertama memberikan interpretasi dan diskusi dari hasil terkait dengan faktor-faktor anteseden ketidaketisan penggunaan komputer dan bagian kedua menyajikan pembahasan hasil efek moderasi pada penelitian ini.

\section{Hipotesis Terkait Etika Kerja Islam}

Analisis data menunjukkan bahwa etika kerja Islam memiliki pengaruh negatif yang signifikan terhadap etika penggunaan komputer (H1: $\beta=-0,714 ; t=9,391)$. Hasil penelitian menunjukkan bahwa etika kerja Islam belum diterapkan secara positif oleh pengguna untuk mencapai etika penggunaan komputer yang baik. Hal ini dibuktikan dengan kurang adanya kesadaran pengguna terhadap pentingnya penerapan etika kerja Islam dalam menjaga etika pada saat menggunakan komputer. Hal tersebut sejalan dengan penelitian Cappel dan Windsor (1998) di mana dapat dikatakan bahwa afiliasi religius dapat menyebabkan perbedaan signifikan dalam sikap pada penggunaan komputer.

\section{Hipotesis Terkait Etika Penggunaan Komputer}

Analisis data menunjukkan bahwa etika penggunaan komputer memiliki pengaruh positif yang signifikan terhadap ketidaketisan penggunaan komputer. $(\mathrm{H} 2: \beta=0,763 ; t=$ $8,656)$. Hasil penelitian menunjukkan bahwa etika penggunaan komputer diterapkan secara positif oleh pengguna untuk meminimalisir terjadinya ketidaketisan penggunaan komputer. Hal ini dibuktikan dengan adanya kesadaran pengguna terhadap pentingnya penerapan etika penggunaan komputer jika ingin meminimalisir terjadinya ketidaketisan penggunaan komputer. Kemudian beberapa penelitian terdahulu mendukung gagasan bahwa etika penggunaan komputer dapat diimplementasikan secara baik guna mengurangi terjadinya ketidaketisan penggunaan komputer dalam suatu organisasi (Namlu dan Odabasi, (2007); Hartono, (2003); Kuo dan Hsu, (2001)).

\section{Hipotesis Terkait Pengaruh Jenis Kelamin}

Gambar 3 dan 4 menyajikan hasil kelompok pria dan wanita pada klasifikasi responden berdasarkan jenis kelamin.

Gambar 3 hubungan antara etika kerja Islam terhadap etika penggunaan komputer adalah tidak signifikan dengan $\mathrm{t}$-statistik sebesar $1,183(<1,64)$ dan nilai $\beta$ positif yaitu 0,893, maka arah hubungan antara etika kerja Islam terhadap etika penggunaan komputer adalah positif. Kemudian hubungan antara etika penggunaan komputer terhadap 


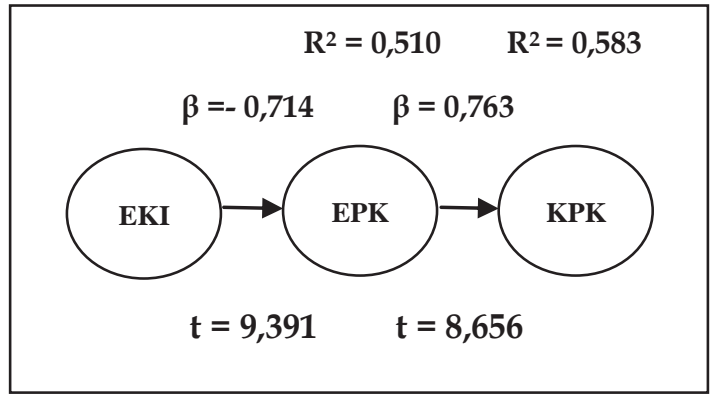

Gambar 2. Hasil Keseluruhan Kelompok

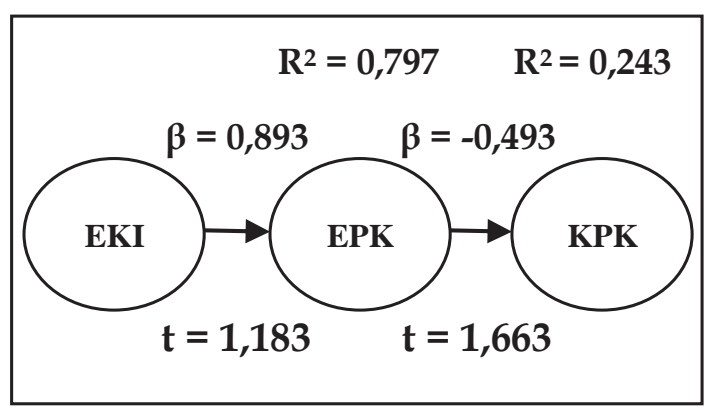

Gambar 3. Hasil Kelompok Pria

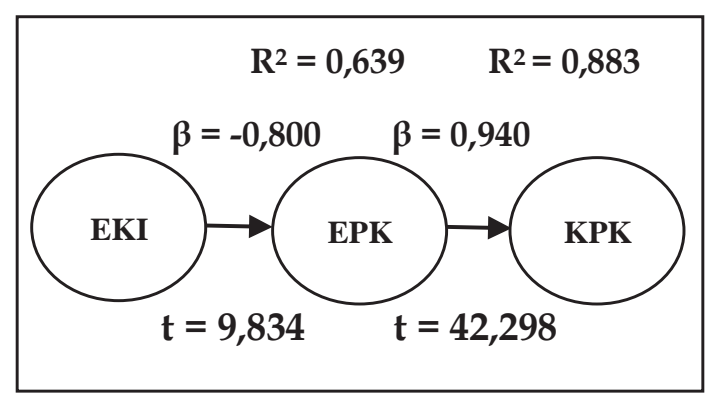

Gambar 4. Hasil Kelompok Wanita

ketidaketisan penggunaan komputer adalah signifikan dengan t-statistik sebesar 1,663 $(>1,64)$ dan nilai $\beta$ negatif yaitu $-0,493$, maka arah hubungan antara etika penggunaan komputer terhadap ketidaketisan penggunaan komputer adalah negatif.

Gambar 4 hubungan antara etika kerja Islam terhadap etika penggunaan komputer adalah signifikan dengan $\mathrm{t}$-statistik sebesar $9,834(>1,64)$ dan nilai $\beta$ negatif yaitu $-0,800$, maka arah hubungan antara etika kerja Islam terhadap etika penggunaan komputer adalah negatif. Kemudian hubungan antara etika penggunaan komputer terhadap ketidaketisan penggunaan komputer adalah signifikan dengan t-statistik sebesar 42,298 $(>1,64)$ dan nilai $\beta$ positif yaitu 0,940 , maka arah hubungan antara etika penggunaan komputer terhadap ketidaketisan penggunaan komputer adalah positif.

Hal tersebut menunjukkan bahwa hipotesis ketiga menyatakan jenis kelamin (pria) berpengaruh negatif terhadap etika kerja Islam, etika penggunaan komputer, serta ketidaketisan penggunaan komputer. Sama halnya dengan jenis kelamin (wanita) berpengaruh negatif terhadap etika kerja Islam dan etika penggunaan komputer, namun berpengaruh positif terhadap etika penggunaan komputer dan ketidaketisan penggunaan komputer. Artinya, jenis kelamin tidak berpengaruh pada penerapan etika kerja Islam, etika penggunaan komputer, dan ketidaketisan penggunaan komputer serta tidak ada dukungan statistik yang ditemukan untuk efek moderasi jenis kelamin terhadap ketiganya. Hasil penelitian menunjukkan bahwa tidak ada perbedaan signifikan antara kelompok pria maupun wanita dalam hubungannya terhadap etika kerja Islam, etika penggunaan komputer, dan ketidaketisan penggunaan komputer. Hal tersebut sejalan dengan penelitian sebelumnya yang menyimpulkan bahwa jenis kelamin tidak berhubungan secara signifikan terhadap etika penggunaan komputer (Mohamed, Karim, dan Hussein, 2012).

\section{Hipotesis Terkait Pengaruh Pengalaman Kerja}

Gambar 5 dan 6 menyajikan hasil kelompok $<2$ tahun dan $\geq 2$ tahun pada klasifikasi responden berdasarkan pengalaman kerja.

Gambar 5 hubungan antara etika kerja Islam terhadap etika penggunaan komputer adalah signifikan dengan t-statistik sebesar $12,771(>1,64)$ dan nilai $\beta$ negatif yaitu $-0,827$, maka arah hubungan antara etika kerja Islam terhadap etika penggunaan komputer adalah negatif. Kemudian hubungan antara etika penggunaan komputer terhadap ketidaketisan penggunaan komputer adalah signifikan dengan t-statistik sebesar 6,461 $(>1,64)$ dan nilai $\beta$ positif yaitu 0,792 , maka arah hubungan antara etika penggunaan komputer terhadap ketidaketisan penggunaan komputer adalah positif.

Gambar 6 hubungan antara etika kerja Islam terhadap etika penggunaan komputer 


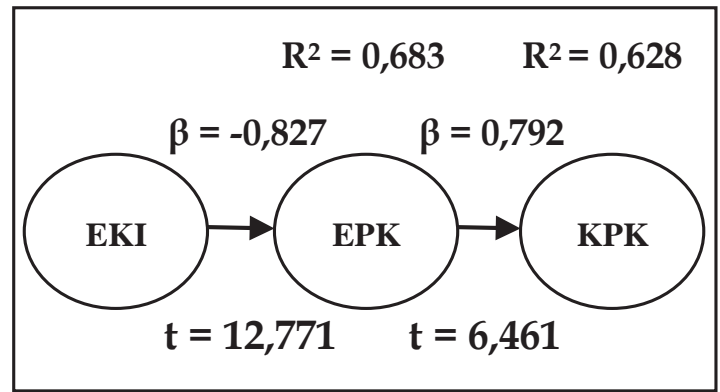

Gambar 5. Hasil Kelompok $<2$ tahun

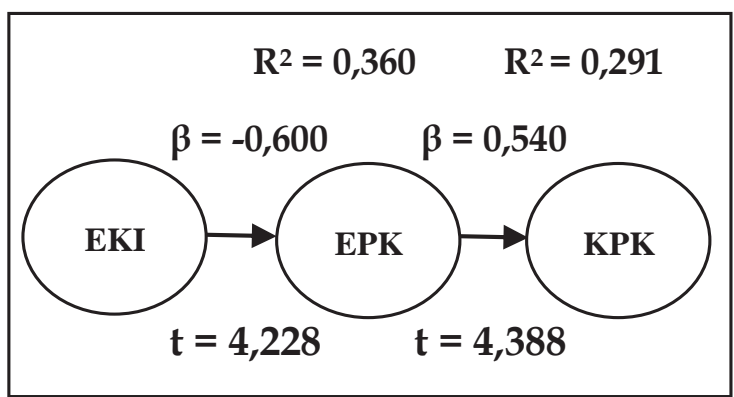

Gambar 6. Hasil Kelompok $\geq 2$ tahun

adalah signifikan dengan t-statistik sebesar $4,228(>1,64)$ dan nilai $\beta$ negatif yaitu $-0,600$, maka arah hubungan antara etika kerja Islam terhadap etika penggunaan komputer adalah negatif. Kemudian hubungan antara etika penggunaan komputer terhadap ketidaketisan penggunaan komputer adalah signifikan dengan t-statistik sebesar 4,388 $(>1,64)$ dan nilai $\beta$ positif yaitu 0,540 , maka arah hubungan antara etika penggunaan komputer terhadap ketidaketisan penggunaan komputer adalah positif.

Hal tersebut menunjukkan bahwa hipotesis keempat menyatakan pengalaman kerja ( $<2$ tahun dan $\geq 2$ tahun) berpengaruh negatif terhadap etika kerja Islam dan etika penggunaan komputer, namun pengalaman kerja ( $<2$ tahun dan $\geq 2$ tahun) berpengaruh positif terhadap etika penggunaan komputer dan ketidaketisan penggunaan komputer. Artinya, pengalaman kerja tidak berpengaruh pada penerapan etika kerja Islam, etika penggunaan komputer, dan ketidaketisan penggunaan komputer. Hasil penelitian menunjukkan bahwa tidak ada perbedaan signifikan antara kelompok $<2$ tahun atau $\geq$ 2 tahun dalam hubungannya terhadap etika kerja Islam, etika penggunaan komputer, dan ketidaketisan penggunaan komputer. Hal tersebut sejalan dengan penelitian sebelumnya yang menyimpulkan bahwa lamanya pengalaman dalam bekerja seseorang dan posisi pekerjaan tidak berhubungan dengan perilaku etis di organisasi (Banerjee, 1996).

\section{KESIMPULAN}

Sesuai dengan pembahasan hasil analisis yang telah dilakukan pada bab sebelumnya, maka terdapat beberapa kesimpulan :

Etika kerja Islam tidak berpengaruh terhadap etika penggunaan komputer. Hal ini menunjukkan pengaruh yang tidak searah antara etika kerja Islam dengan etika penggunaan komputer. Sehingga pada dasarnya semakin positif pengaruh etika kerja Islam, maka hasil tersebut dapat dipergunakan untuk pengambilan keputusan di masa yang akan datang dan pada akhirnya akan meningkatkan etika penggunaan komputer.

Etika penggunaan komputer berpengaruh positif terhadap ketidaketisan penggunaan komputer. Hal ini menunjukkan pengaruh yang searah (positif) antara etika penggunaan komputer dengan ketidaketisan penggunaan komputer. Sehingga semakin positif hasil dari etika penggunaan komputer, maka hasil tersebut dapat dipergunakan untuk pengambilan keputusan di masa yang akan datang dan pada akhirnya akan mengurangi ketidaketisan penggunaan komputer.

Jenis kelamin tidak berpengaruh terhadap ketidaketisan penggunaan komputer. Hal ini menunjukkan pengaruh yang tidak searah antara jenis kelamin dengan ketidaketisan penggunaan komputer. Sehingga pada dasarnya semakin positif pengaruh jenis kelamin, maka hasil tersebut dapat dipergunakan untuk pengambilan keputusan di masa yang akan datang dan pada akhirnya akan mengurangi ketidaketisan penggunaan komputer.

Pengalaman kerja tidak berpengaruh terhadap ketidaketisan penggunaan komputer. Hal ini menunjukkan pengaruh yang tidak searah antara pengalaman kerja dengan ketidaketisan penggunaan komputer. Sehingga pada dasarnya semakin positif pengaruh pengalaman kerja, maka hasil tersebut dapat dipergunakan untuk pengambilan keputusan di masa yang akan datang dan akan mengurangi ketidaketisan penggunaan komputer. 
Jumlah responden yang lebih tinggi akan menjadikan hasil yang lebih baik. Oleh karena itu, diharapkan penelitian selanjutnya dapat melibatkan responden secara lebih luas, seperti mengikutsertakan responden pada lingkup Provinsi Daerah Istimewa Yogyakarta.

\section{DAFTAR PUSTAKA}

Abdillah, W. dan Jogiyanto, H. M. (2009), Konsep Dan Aplikasi PLS (Partial Least Square) Untuk Penelitian Empiris, Badan Penerbit Fakultas Ekonomi Dan Bisnis UGM, Yogyakarta.

Ali, A. J. dan Al-Owaihan, A. (2008), "Islamic work ethic: a critical review", Cross Cultural Management Development, Vol. 14, No. 6, pp. 5-19.

Arikunto, S. (2006), Prosedur Penelitian Suatu Pendekatan Praktik, Rineka Cipta, Jakarta.

Asifudin, A.J. (2004), Etos Kerja Islami, Muhammadiyah University Press, Surakarta.

Baaese, S. (2003), “A gift of fire. Social, Legal and Ethical Issues for Computers and Internet $\left(2^{\text {nd }}\right.$ ed.)". New Jersey : PrenticeHall.

Banerjee, D., Jones, T. W. dan Cronan, T. P. (1996), "The association of demographic variables and ethical behavior of information systems personnel", Industrial Management \& Data Systems, Vol. 96, No.3, pp. 3-10.

Bertens, K. (2007). Etika, Jakarta : PT Gramedia Pustaka Utama.

Cappel, J. J. dan Windsor, J. C. (1998), «A comparative investigation of ethical decision making : information systems professionals versus students», The Database for Advances in Information Systems, Vol. 29, No. 2, pp 20-34.

Chin, W. W. (1998), «The Partial Least Squares Approach for Structural Equation Modeling», In Marcoulides, G.A. (Ed), Modern Method for Business Research, Mahwah, NJ, Erlbaum Associates, hal. 295-358.

Cooper, Donald R., dan Pamela, S. Schindler. (2006). Metode Riset Bisnis, Volume 1. PT Media Global Edukasi. Jakarta.
Dawson, L. M. (1997), “Ethical differences between men and women in the sales profession", Journal of Business Ethics, Vol. 16, No. 11, pp. 1143-52.

Fornell, C., dan Larcker, D. (1981), “Evaluating Structural Equation Models with Unobservable and Measurement Error", Journal of Marketing Research, Vol. 18, hal. 39-50.

Ghozali, I. (2006), Structural Equation Modeling Metode Alternatif dengan PLS (Kedua ed.), BP Undip, Semarang.

Hair, et. al., (2006), Multivariate Data Analysis $6^{\text {th }}$ Ed, Pearson Education, New Jersey.

Hartono, J. (2003), Sistem Teknologi Informasi, Edisi I, Andi, Yogyakarta.

Hartono, J. M. (2007), Sistem Informasi Keperilakuan, Erlangga, Yogyakarta.

Hartono, (2008), SPSS 16.0, Analisis Data Statistika dan Penelitian, Pustaka Pelajar, Yogyakarta.

Jananto, A. (2003), "Pentingnya Etika Dalam Penggunaan Komputer", Jurnal Fakultas Teknologi Informasi, Universitas Stikubank, Semarang.

Kadafi, A. H. (2012), “Etika dalam Penggunaan Komputer dan Teknologi serta Hukum yang Mengatur Etika dalam Penggunaan Komputer dan Teknologi", Jurnal Sekolah Tinggi Manajemen Informatika dan Komputer, Perguruan Tinggi Teknokrat, Lampung.

Kadir, A. (2014), Pengenalan Sistem Informasi, Edisi Revisi, Andi, Yogyakarta.

Karim, N. S. A., Zamzuri, N. H. A. dan Mohamad, Y. N. (2009), “Exploring the Relationship between internet ethics and the big five model of personality", Computers $\mathcal{E}$ Education, Vol. 53, No. 1, pp. 86-93.

Kell, W.G., R.N. Johnson dan W.C. Boynton. (2002). Modern Auditing. Edisi Ketujuh, Jilid I, Erlangga, Jakarta.

Kreie, J. dan Cronan, T. P. (1998), "How men and women view ethics", Communications of the ACM , Vol. 41, No. 9, pp. 70-6.

Krismiaji, (2015), Sistem Informasi Akuntansi, Unit Penerbit, Yogyakarta.

Kuo, Feng-Yang \& Hsu, Meng-Hsiang, (2001), “Developmentand Validation of Ethical 
Computer Self Efficacy Measure: The Case Softlifting, Journal of Business Ethics, Vol. 32, pp. 299-315.

Loch, K. D. dan Conger, S. (1996), “Evaluating ethical decision making and computer use", Communications of the ACM, Vol. 39, No. 7, pp. 74-83.

Ludigdo, Unti dan M. Machfoedz. (1999). "Persepsi Akuntan dan mahasiswa Terhadap Etika Bisnis. Jurnal Riset Akuntansi Indonesia Vol . 2 : 1-9.

Maryani, T. dan U. Ludigdo. (2001). Survei Atas Faktor-faktor yang Mempengaruhi Sikap dan Perilaku Etis Akuntan. TEMA. Volume II Nomor 1. Maret 49-62.

Mohamed, N., Karim, N. S. A. dan Hussein, R. (2012), "Computer use ethics among university students and staffs, the influence of gender, religious work value and organizational level", Computer use Ethics, Vol. 29, No. 5, pp. 328-43.

Moor, J. H. (1985), "What is computer ethics?", Metaphilosophy, Vol. 16 No. 4, hal. 266-75.

Moores, T. T. dan Chang, J. (2006), "Ethical decision making in software piracy: initial development and test of a fourcomponent model", MIS Quarterly, Vol. 30, No. 10, hal. 167-80.

Muawanah, Umi dan Nur Indriantoro. (2001). "Perilaku Akuntan Publik dalam Situasi Konflik Audit : Peran Locus of Control, Komitmen Profesi dan Kesadaran Etis", Jurnal Riset Akuntansi Indonesia (Mei): 13-147.

Mulyadi, (2014), Sistem Akuntansi, Cetakan Ke4, Salemba Empat, Jakarta.

Muthmainah, S. (2006). "Studi Tentang Perbedaan Evaluasi Etis, Intensi Etis, dan Orientasi Etis Dilihat dari Gender dan Disiplin Ilmu: Potensi Rekruitment Staf Profesional pada Kantor Akuntan Publik". Simposium Nasional Akuntansi IX, Padang.

Namlu, A. G. dan Odabasi, H. F. (2007), "Unethical computer using behavior scale: A study of reliability and validity on Turkish University Students", Computers $\mathcal{E}$ Education, pp. 205-15.

Peterson, D. K. (2002), “Computer ethics: the influence of guidelines and universal moral beliefs", Information Technology and People, Vol. 15, No. 4, pp. 346-61.

Ranupandojo, H., dan Suad Husnan. (1984), Manajemen Personalia, Edisi III, Yogyakarta: BPFE.

Sekaran, U. (2003), Research Methods for Business: A Skill Building Approach, Fourth Edition, John Wiley \& Sons, Inc., New York.

Sugiyono, (2003), Metopel Bisnis, Cetakan III, Alfabeta, Bandung.

Sugiyono, (2012), Metode Penelitian Administrasi, Cetakan Ke-20, Alfabeta, Bandung.

Sugiyono, (2014), Metode Penelitian Pendidikan Pendekatan Kuantitatif, Kualitatifdan RED, Alfabeta, Bandung.

Umar, (2011), Metode Penelitian Untuk Skripsi dan Tesis Bisnis, Jakarta: Rajawali

Urumsah, D. (2014), Perencanaan Strategis Sistem Informasi, Cetakan I, Data Algonia, Yogyakarta.

Usman, H. (2011), Manajemen : Teori Praktik dan Riset Pendidikan, Bumi Aksara, Jakarta.

Wijayana dan Nurul H. (2009), “Tantangan Jurnalis di Era Cyber", (http://staff.undip. ac.id/fisip/Nurul/archives/41). 